\title{
Correction to: Impact of Sexualized Substance Use and Other Risk Practices on HCV Microelimination in gbMSM Living with HIV: Urgent Need for Targeted Strategies. Results of a Retrospective Cohort Study
}

\author{
María Martínez-Rebollar · Lorena De La Mora • Miriam Campistol • \\ Bruno Cabrera · Albert Bagué · Elisa De Lazzari · Berta Torres • Ana González-Cordón • \\ Alexy Inciarte · Juan Ambrosioni · Esteban Martínez · José L. Blanco • \\ Xavier Forns · Jordi Blanch · Josep Mallolas · Montserrat Laguno (D) \\ Published online: February 16, 2022 \\ (C) The Author(s) 2022
}

Correction to: Infect Dis Ther (2021) 10:1253-1266

https://doi.org/10.1007/s40121-021-00448-0

In the original publication of the article, the article funding note was incorrectly published, the correct one should read as: This study has

The original article can be found online at https://doi. org/10.1007/s40121-021-00448-0.

M. Martínez-Rebollar · L. De La Mora .

M. Campistol · B. Cabrera · A. Bagué .

E. De Lazzari · B. Torres · A. González-Cordón ·

A. Inciarte $\cdot \mathrm{J}$. Ambrosioni · E. Martínez .

J. L. Blanco · J. Mallolas · M. Laguno $(\varangle)$

Department of Infectious Diseases, HIV Unit,

Hospital Clinic and IDIBAPS, Barcelona University,

Barcelona, Spain

e-mail: mlaguno@clinic.cat

\section{Forns}

Liver Unit, Hospital Clinic, IDIBAPS, University of Barcelona and CIBEREHD, Barcelona, Spain

\section{J. Blanch}

Psychiatry and Psychology Department, Hospital Clinic and CIBERSAM, Barcelona University,

Barcelona, Spain been funded by Instituto de Salud Carlos III through the project "PI18/00583" and co-funded by European Regional Development Fund "A way to make Europe".

This has been corrected in this paper.

\section{OPEN ACCESS}

This article is licensed under a Creative Commons Attribution-NonCommercial 4.0 International License, which permits any noncommercial use, sharing, adaptation, distribution and reproduction in any medium or format, as long as you give appropriate credit to the original author(s) and the source, provide a link to the Creative Commons licence, and indicate if changes were made. The images or other third party material in this article are included in the article's Creative Commons licence, unless indicated otherwise in a credit line to the material. If material is not included in the article's Creative Commons licence and your intended use is not permitted by statutory regulation or exceeds the permitted use, you will need to obtain permission directly from the copyright holder. To view a copy of this licence, visit http://creativecommons.org/licenses/by$\mathrm{nc} / 4.0 /$. 